\title{
Scleroderma and erosive polyarthritis: a disease entity?
}

\author{
R. D. ARMSTRONG AND T. GIBSON \\ From the Department of Rheumatology, Guy's Hospital, St Thomas Street, London SE1 9RT
}

SUMMARY We describe 4 patients with scleroderma in whom a major clinical feature was a deforming, erosive polyarthritis accompanied by positive tests for rheumatoid factor. In all but 1 case the skin involvement preceded joint symptoms, and in some cases there was evidence of systemic involvement. This destructive arthritis may represent the coexistence of 2 diseases or an extreme form of the inflammatory arthritis seen in scleroderma. Alternatively, the clinical presentation may represent an 'overlap syndrome' with features of both scleroderma and rheumatoid arthritis.

The occurrence of an arthropathy in patients with scleroderma is well recognised and was first described in $1847 . .^{1}$ The joint manifestations may be partly attributed to thickening and loss of elasticity of skin and periarticular tissues or to tethering of skin to subcutaneous tissue. ${ }^{2} 3$ These changes lead to joint contractures and may on occasion obscure the inflammatory synovitis which is also known to occur and whose nature was recognised as long ago as $1898 .{ }^{4}$ The arthritis is seldom severe in radiological terms, but erosive changes have been described. ${ }^{5-7}$ Commoner radiological findings compatible with an inflammatory arthritis are loss of joint space and juxta-articular osteoporosis. ${ }^{8-11}$ The 4 patients described here had scleroderma and a joint disorder which resembled rheumatoid arthritis. Coexistence of the clinical features of these 2 conditions raises important questions about their aetiology and whether in this situation they can be considered as part of the same disease process.

\section{Case reports}

The patients described below were referred to the Department of Rheumatology, Guy's Hospital, during a 16-year period from 1954 to 1970 . Their more important clinical and laboratory features are summarised in Tables 1 and 2.

\section{CASE 1}

A 56-year-old white woman developed Raynaud's phenomenon affecting the hands in 1951. At this time it was noted that she had sclerodactyly and

Accepted for publication 4 March 1981.

Correspondence to Dr T. Gibson.
Table 1 Clinical features of cases 1-4

\begin{tabular}{|c|c|c|c|c|}
\hline Case & $\begin{array}{l}\text { Age } \\
\text { (years) }\end{array}$ & $\begin{array}{l}\text { Disease } \\
\text { duration } \\
\text { (years) }\end{array}$ & Skin abnormalities & Additional features \\
\hline 1 & 56 & 29 & $\begin{array}{l}\text { Raynaud's pheno- } \\
\text { menon, } \\
\text { sclerodactyly, } \\
\text { telangiectasia, } \\
\text { restricted mouth } \\
\text { opening }\end{array}$ & \\
\hline 2 & 68 & 20 & Sclerodactyly & $\begin{array}{l}\text { Keratoconjunctivitis } \\
\text { sicca, myxoedema }\end{array}$ \\
\hline 3 & 68 & 13 & $\begin{array}{l}\text { Raynaud's pheno- } \\
\text { menon, } \\
\text { sclerodactyly, } \\
\text { restricted mouth } \\
\text { opening }\end{array}$ & Myositis \\
\hline 4 & 60 & 27 & $\begin{array}{l}\text { Raynaud's pheno- } \\
\text { menon, } \\
\text { sclerodactyly, } \\
\text { telangiectasia }\end{array}$ & $\begin{array}{l}\text { Keratoconjunctivitis } \\
\text { sicca, dysphagia, } \\
\text { diarrhoea (malab- } \\
\text { sorption) }\end{array}$ \\
\hline
\end{tabular}

telangiectasia on arms, face, and back. A skin biopsy confirmed the clinical diagnosis of scleroderma. Oral steroid therapy was instituted in 1958 at a daily does of $10 \mathrm{mg}$ prednisolone and has continued at a lower dose until the present time.

In 1963 she developed a symmetrical polyarthritis affecting wrists and small joints of the hands (Fig. 1) which necessitated hospital admission in 1970. At that time investigations revealed ESR $22 \mathrm{~mm} / \mathrm{h}$; RA latex positive, differential agglutination test (DAT) 16, and antinuclear factor (ANF) negative. One year later symmetrically distributed 
Table 2 Investigation results. Case 4 also had low serum iron and folate, increased faecal fat excretion, and an abnormal barium follow-through examination with widening of small-bowel loops and mucosal thickening. A jejunal biopsy was normal, but jejunal aspiration revealed an increase in resting juice and bacterial overgrowth.

\begin{tabular}{|c|c|c|c|c|c|c|c|c|}
\hline \multirow[t]{2}{*}{ Case } & \multicolumn{3}{|l|}{$\mathrm{X}$-rays } & \multirow{2}{*}{$\begin{array}{l}E S R \\
(\mathrm{~mm} / \mathrm{hr})\end{array}$} & \multirow{2}{*}{$\begin{array}{l}R F \\
(D A T)\end{array}$} & \multirow[t]{2}{*}{$A N F$} & \multirow[t]{2}{*}{$R N P$} & \multirow{2}{*}{$\begin{array}{l}\text { Respiratory function } \\
\text { tests }\end{array}$} \\
\hline & Hands & Chest & $\begin{array}{l}\text { Barium } \\
\text { swallow }\end{array}$ & & & & & \\
\hline 1 & Erosions & $\begin{array}{l}\text { Basal } \\
\text { fibrosis }\end{array}$ & Normal & 55 & 128 & Positive & Negative & $\begin{array}{l}\text { Normal } \\
\text { (including transfer factor) }\end{array}$ \\
\hline 2 & $\begin{array}{l}\text { Erosions } \\
\text { Calcinosis }\end{array}$ & $\begin{array}{l}\text { Basal } \\
\text { fibrosis }\end{array}$ & Normal & 24 & 4 & Positive & Negative & $\begin{array}{l}\text { Severe restrictive } \\
\text { defect. } \\
\text { Vital capacity too low to } \\
\text { measure transfer factor }\end{array}$ \\
\hline 3 & Erosions & $\begin{array}{l}\text { Basal } \\
\text { fibrosis }\end{array}$ & $\begin{array}{l}\text { Impaired } \\
\text { oesophageal } \\
\text { motility }\end{array}$ & 99 & 1024 & Negative & Not done & $\begin{array}{l}\text { Moderate restrictive defect. } \\
\text { Transfer factor not measured. }\end{array}$ \\
\hline 4 & $\begin{array}{l}\text { Erosions } \\
\text { Calcinosis }\end{array}$ & $\begin{array}{l}\text { Basal } \\
\quad \text { fibrosis }\end{array}$ & $\begin{array}{l}\text { Oesophageal } \\
\text { stricture }\end{array}$ & 14 & 2048 & Positive & Not done & $\begin{array}{l}\text { Outflow obstruction. } \\
\text { Low gas transfer factor }\end{array}$ \\
\hline
\end{tabular}

ESR = erythrocyte sedimentation rate. $\quad \mathbf{R F}=$ rheumatoid factor. $\quad$ DAT $=$ differential agglutination test. $\quad A N F=$ antinuclear factor. RNP =ribonucleoprotein.

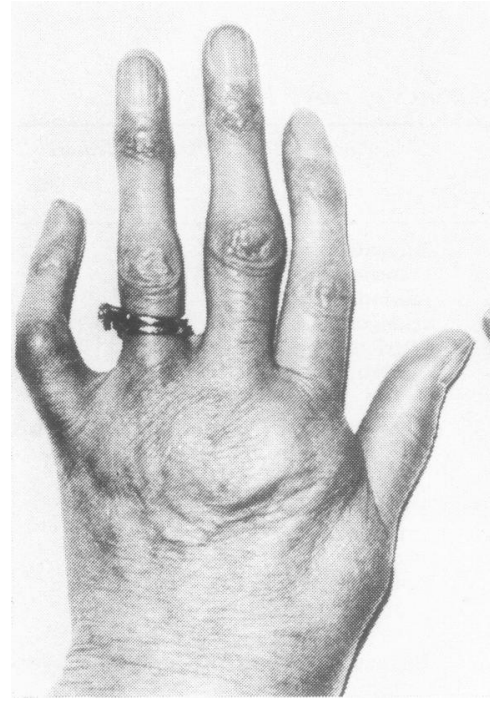

marginal erosions were visible in the small joints of the hands on $x$-ray (Fig. 2). There has been a progression in the joint destruction but not the skin manifestations. Investigations in 1979 showed ESR $55 \mathrm{~mm} / \mathrm{h}$, DAT 128 , positive ANF, and a normal barium swallow. A chest $x$-ray revealed unequivocal basal pulmonary fibrosis, but respiratory function tests were normal on the single occasion they were performed.

\section{CASE 2}

This 68-year-old white woman developed sclerodactyly in 1960. In 1974 she was admitted to hospital with a symmetrical arthritis and keratoconjunctivitis
Fig. 1 Case 1. Photograph of hands showing sclerodactylyl and $a$ symmetrical arthritis affecting severai metacarpophalangeal and proximal interphalangeal joints sicca. At that time relevant investigations were ESR $6 \mathrm{~mm} / \mathrm{h}$, diffuse rise in gamma globulins, strongly positive thyroid microsomal antibody, low serum thyroxine, and positive RA latex and ANF tests. Her arthritis progressed, and treatment with Dpenicillamine was attempted but discontinued because of a rash. In 1977 she showed signs of a generalised arthritis with flexion deformities of the knees. She was also noted to have leg ulcers, restriction of mouth opening, and loss of finger pulp. $X$-rays of the hands and feet showed a symmetrical, destructive, deforming arthritis with erosive changes and calcinosis (Fig. 3). Additional investigations are outlined in Table 2. 


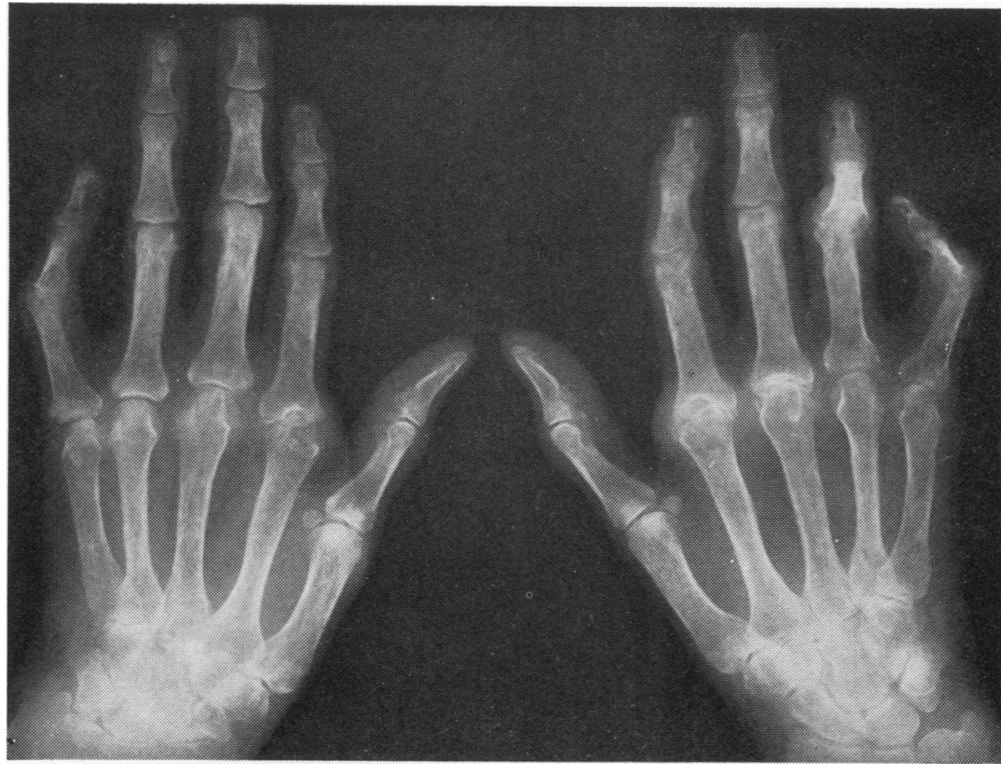

Fig. 2 Case 1. X-ray of hands showing loss of joint space and erosive change

\section{CASE 3}

This 68-year-old white woman reported the onset of Raynaud's phenomenon, swollen fingers, and aching knees in 1967. Pregangrenous change of the left middle fingertip reversed following intravenous dextran 40 (Rheomacrodex) infusions and corticosteroid therapy. At that time investigations showed: ESR $20 \mathrm{~mm} / \mathrm{h}$, LE cells negative, and RA latex negative. The following year bilateral axillary sympathectomy was performed, with some relief of her Raynaud's phenomenon.

In 1970 sclerodactyly was noted, and a clinical diagnosis of scleroderma was proposed. D-penicillamine treatment was initiated without benefit. At this time she also had a mild myositis confirmed by electromyography (EMG). The creatine phosphokinase (CPK) result is unavailable and a muscle biopsy was not performed. The RA latex test was positive but the Rose-Waaler test was negative. By 1975 her scleroderma had progressed, with perioral skin involvement, telangiectasia, and evidence of lung and oesophageal involvement (see Table 2 for details). Her ANF test was negative, and the EMG now showed only mild myopathic changes.

In May 1979 she complained of pronounced morning stiffness, pain, and swelling affecting knees, ankles, hips, hands, and shoulders. $X$-rays revealed erosions in her small hand joints. Other investigations showed ESR $99 \mathrm{~mm} / \mathrm{h}, \mathrm{Hb} 8 \cdot 3 \mathrm{~g} / \mathrm{dl}, \mathrm{RA}$ latex positive, DAT 1024, and ANF negative. She was treated with intensive physiotherapy, intra-articular steroid injections, and nonsteroidal anti-inflam- matory drugs. She was reluctant to accept further hospital attention and became bed-bound because of her arthritis.

CASE 4

This 60-year-old white woman described the onset of Raynaud's phenomenon affecting hands and feet in 1953. In 1965 a hiatus hernia was diagnosed, and the following year she received treatment for a left corneal ulcer which was related to the presence of keratoconjunctivitis sicca. In 1970 she developed a symmetrical polyarthritis. A vagotomy and gastroenterostomy was performed in 1971 for duodenal ulceration, and the following year she had further surgery for an oesophageal stricture. At this time she was noted to have sclerodactyly and telangiectasia on the hands and face, with restricted mouth opening (Fig. 4). Subcutaneous calcinosis was noted on $x$-rays of the hands.

In 1973 she presented with weight loss and deteriorating arthritis. Investigations revealed $\mathrm{Hb}$ $9.2 \mathrm{~g} / \mathrm{dl}$ (hypochromic, microcytic film), ESR $92 \mathrm{~mm} / \mathrm{h}$, low serum folate, normal vitamin $B_{12}$, positive ANF, DAT 2048, and increased faecal fat excretion. A barium follow-through showed reduced small bowel motility. She had normal mucosal appearances on jejunal biopsy but duodenal fluid aspiration revealed moderate bacterial overgrowth. Symmetrical erosions were noted on hand radiographs (Fig. 5). Her severe constitutional disturbance responded to treatment with D-penicillamine, phthalylsulphathiazole, and folic acid, but her 


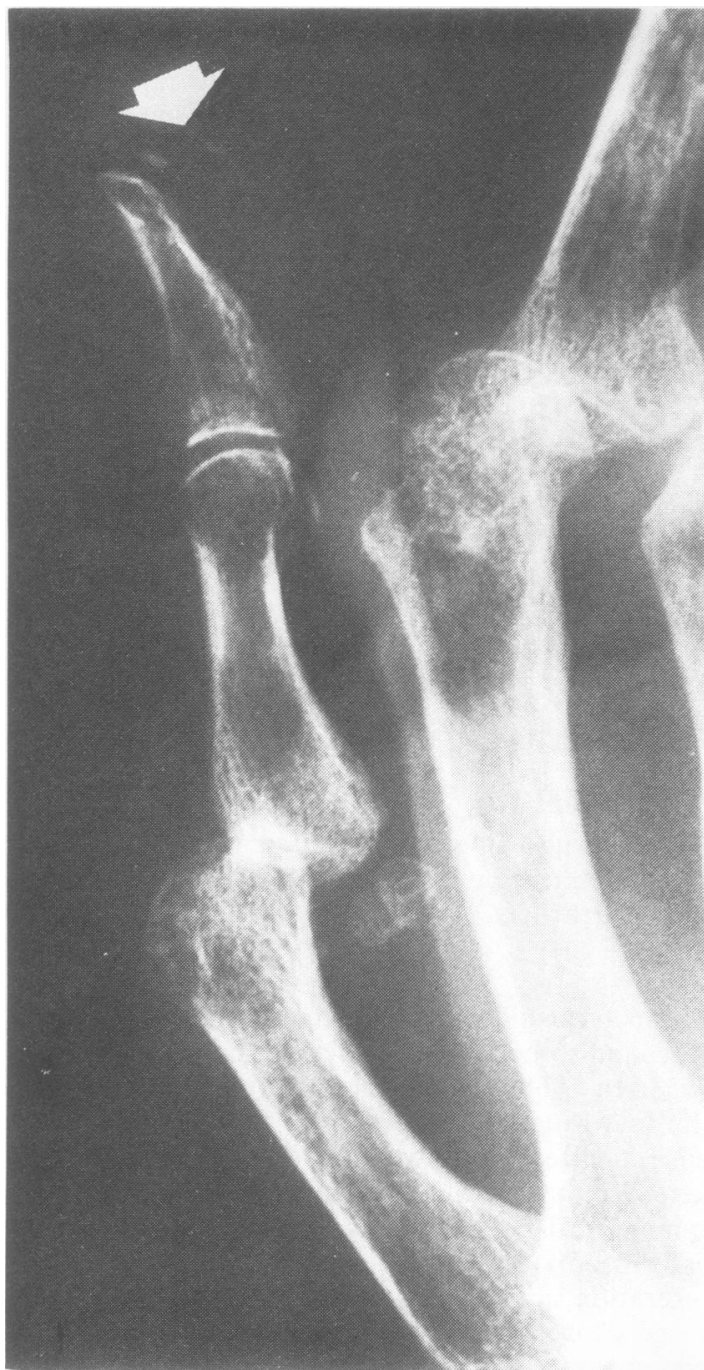

Fig. 3 Case 2. X-ray of right thumb showing subcutaneous calcinosis (arrow). Erosive change is seen at the first and second MCP joints accompanied by subluxation

arthritis progressed. In 1976 she underwent a left knee synovectomy, and after an episode of septic arthritis of the contralateral knee joint a right total knee replacement was performed in 1978.

\section{Discussion}

Patients who develop the typical clinical features of scleroderma may present with predominantly articular symptoms and signs, and this may lead to an early provisional diagnosis of rheumatoid

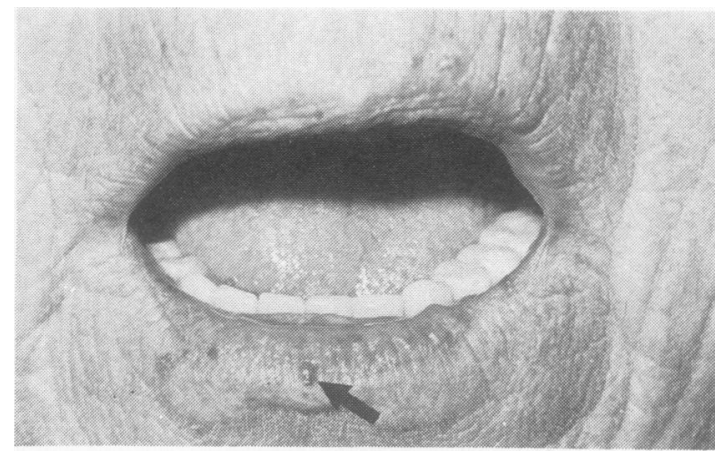

Fig. 4 Case 4. Photograph of mouth showing restricted aperture, puckering of circumoral skin, and telangiectasia (arrow).

arthritis and even specific treatment for this condition. ${ }^{12-15}$ In only 1 of our patients (case 3 ) was arthritis a prominent symptom at the time of presentation. In the remainder the initial features were those of sclerodermatous skin involvement and Raynaud's phenomenon. Subsequently they developed arthritis and visceral involvement as reflected by abnormal oesophageal motility, impaired lung function, or malabsorption. In all 4 cases skin involvement was mild, and the most striking feature was the severity of the polyarthritis.

In Tuffanelli and Winkelmann's ${ }^{11}$ large series of patients with scleroderma articular changes were encountered in $46 \%$ of patients. In $12 \%$ the illness was heralded by articular symptoms, and in many the initial diagnosis was of an arthritis. Of those whose hands were $x$-rayed $62 \%$ showed abnormalities, including osteoporosis, narrowed joint spaces, periarticular soft tissue swelling, and 'arthritic changes in small joints.' Erosive change was not specifically mentioned. Thirty-one patients were considered to show an overlap with rheumatoid arthritis, but further details were not given. In 1965 Kemp Harper and Jackson ${ }^{16}$ reported the radiological findings in 52 scleroderma patients who had been seen over 15 years. No erosive changes were documented. In another study Rabinowitz et al. $^{5}$ reviewed the hand and wrist $x$-rays of 24 patients with scleroderma. All had mild arthralgia or arthritis, and bone erosions were seen in 13 patients. The $x$-rays of 7 patients showed many features in common with rheumatoid arthritis. More recently Lovell and Jayson ${ }^{6}$ examined the $x$-rays of another 24 patients with scleroderma: 11 had definite radiological abnormalities of joints in the hands and wrists, and, of these, 5 had erosions. The erosive changes were usually minor and the authors felt that they were not typical of rheumatoid arthritis. 


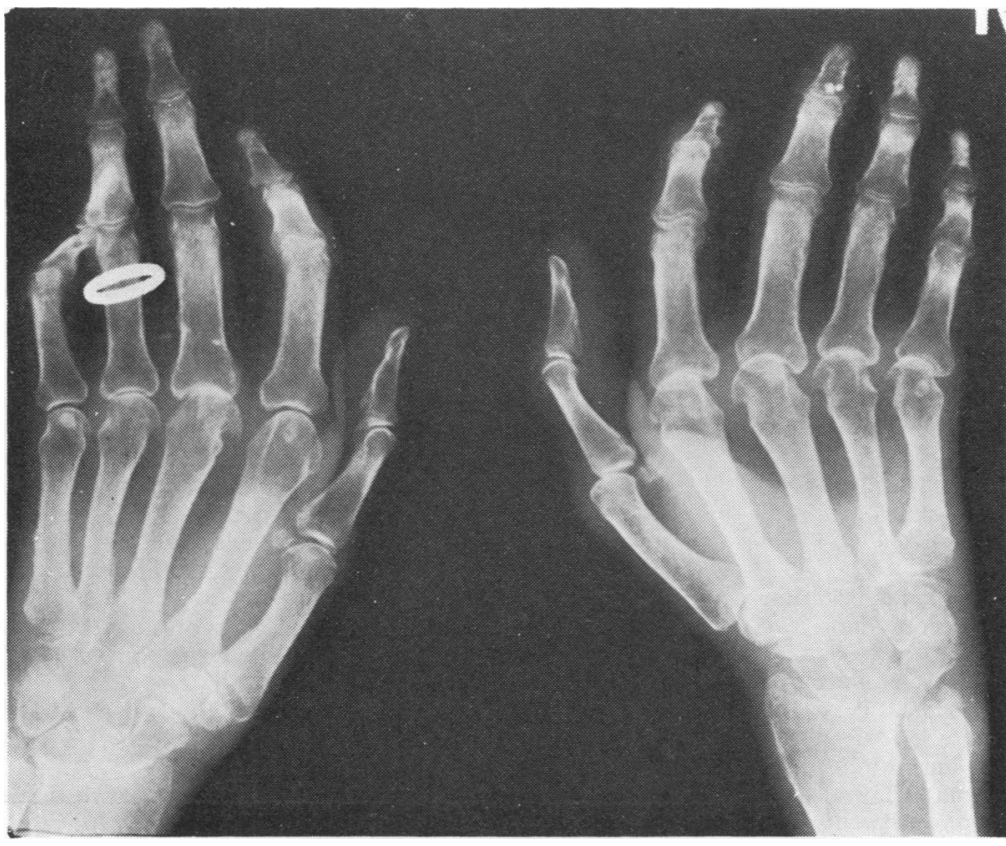

Fig. 5 Case 4. X-ray of hands showing widespread loss of joint space, erosions (note hook-like erosion of head of middle metacarpal on left hand) and calcinosis.

It is noteworthy that all our patients had positive tests for rheumatoid factor. This may occur in $30 \%$ of patients with scleroderma, and Clark et al. ${ }^{17}$ found a correlation between inflammatory synovial biopsy appearances and the presence of rheumatoid factor in the serum or synovial fluid. They noted no relationship between disease duration and the synovial biopsy appearances. Kellgren and Ball ${ }^{18}$ believed that high titres of rheumatoid factor tended to occur in patients with prominent articular features. However, this was not confirmed by Rodnan ${ }^{10}$ in his study of 29 patients.

The clinical picture of our patients bears some resemblance to that of mixed connective tissue disease (MCTD), first described by Sharp et al. ${ }^{19}$ Sclerodermatous features may be found in association with those of systemic lupus erythematosus (SLE) and dermatomyositis. Arthritis and arthralgia are very common presenting features of this condition, ${ }^{19-24}$ and a mistaken diagnosis of rheumatoid arthritis occurs frequently. ${ }^{212324}$ Occasionally the diagnosis of rheumatoid arthritis may be sufficiently convincing to warrant gold therapy. ${ }^{21}$ In some studies typical rheumatoid nodules have been noted, ${ }^{20} 25$ and in one series small joint erosions were described in $60 \%$ of cases. ${ }^{23}$ Rheumatoid factor, although often present, ${ }^{20-22}$ does not correlate with severe joint manifestations. A sine qua non for the diagnosis of MCTD is the presence of antibody to the ribonucleoprotein (RNP) component of an extract- able nuclear antigen (ENA). This was not detected in either of our patients who were tested for this antibody.

It has been disputed whether MCTD is a disease entity distinct from SLE or merely part of a disease spectrum. A similar diagnostic dilemma exists for our patients. There were clinical, radiological, and serological features consistent with rheumatoid arthritis, but the cutaneous and systemic involvement suggest that the arthritis may have represented part of the spectrum of scleroderma. Conceivably each patient was afflicted by 2 separate yet simultaneous diseases. Alternatively they were examples of a distinct overlap syndrome in which mild skin involvement was associated with internal organ disease and a florid erosive arthritis. The existence of such a clinical syndrome has not been generally acknowledged. Our patients have been the subject of considerable semantic discussion which has impinged not only on their precise diagnosis but also on their appropriate management. It remains to be seen whether such patients warrant emphasis as a separate disease entity and whether the demonstration of antibodies, such as that directed against polyuridylic acid in scleroderma, ${ }^{26}$ will prove sufficiently specific to allow better delineation of connective tissue diseases which share common clinical features.

We are most grateful to Professor G. S. Panayi and Dr R. Grahame for permission to report patients under their care. 


\section{References}

1 Forget C P. Mémoire sur le chorionitis ou la sclerostenose cutanée (maladie non décrite par les auteurs). Gaz Med Strasbourg 1847; 7: 200-12.

2 Clinico-pathologic conference. Scleroderma with congestive heart failure. Am J Med 1953; 14: 231-9.

3 Jablonska S, Bubnow B, Lukasiak B. Acrosclerosis: a disease sui generis or a variety of diffuse scleroderma? Br J Dermatol 1959; 71: 123-33.

4 Osler W. On diffuse scleroderma: with special reference to diagnosis and the use of thyroid gland extract. J Cutan Genito-urin Dis 1898; 16: 49-67; 127-34.

5 Rabinowitz J G, Twersky J, Guttadauria M. Similar bone manifestations of scleroderma and rheumatoid arthritis. Radiology 1974; 121: 35-44.

6 Lovell C R, Jayson M I V. Joint involvement in systemic sclerosis, Scand J Rheumatol 1979; 8: 154-60.

7 Wild W, Beetham W P. Erosive arthropathy in systemic scleroderma. JAMA 1975; 232: 511-2.

8 Rodnan G P, Medsger T A. The rheumatic manifestations of progressive systemic sclerosis (scleroderma). Clin Orthop 1968; 8: 81-93.

9 Kinder R C, Fleischmajer R. Systemic scleroderma: a review of organ systems. Int $J$. Dermatol 1974; 13: 382-95.

10 Rodnan G P. The nature of joint involvement in progressive systemic sclerosis (diffuse scleroderma). Clinical study and pathologic examination of synovium in twenty-nine patients. Ann Intern Med 1962; 56: 422-39.

11 Tuffanelli D L, Winkelmann R K. Systemic scleroderma: a clinical study of 727 cases. Arch Dermatol 1961; 84: 359-71.

12 Leinwand I, Duryee A W, Richter M N. Scleroderma (based on a study of over 150 cases). Ann Intern Med $1954 ; 41: 1003-42$.

13 Talbott J H, Ferrandis R M. Collagen Diseases. New York: Grune and Stratton, 1956: 137.
14 Orabona M L, Albano D. Systemic progressive sclerosis (or visceral scleroderma). Review of the literature and report of cases. Acta Med Scand 1957; 160: suppl 133.

15 LaTona $S \mathrm{R}$. Arthropathy in the unusual connective tissue (collagen) diseases. In: Talbott $\mathbf{J} \mathbf{H}$, Lockie $\mathbf{L} \mathbf{M}$, eds. Progress in Arthritis. New York: Grune and Stratton, 1958: 429.

16 Harper $R$ A K, Jackson D C. Progressive systemic sclerosis. Br J Radiol 1965; 38: 825-34.

17 Clark J A, Winkelmann R K, McDuffie F C, Ward L E. Synovial tissue changes and rheumatoid factor in scleroderma. Mayo Clin Proc 1971 ; 46: 97-103.

18 Kellgren J H, Ball J. Clinical significance of the rheumatoid serum factor. $\mathrm{Br}$ Med $J 1959$; i: 523-31.

19 Sharp G C, Irvin W S, Tan E M, Gould R G, Holman $H$ R. Mixed connective tissue disease-an apparently distinct rheumatic disease syndrome associated with a specific antibody to an extractable nuclear antigen (ENA). Am J Med 1972; 52: 148-59.

20 Ramos-Niembro F, Alarcon-Segovia D, HernandezOrtiz. Articular manifestations of mixed connective tissue disease. Arthritis Rheum 1979; 22: 43-51.

21 Halla J T, Hardin J G. Clinical features of the arthritis of mixed connective tissue disease. Arthritis Rheum 1978; 21: 497-503.

22 Peskett S A, Ansell B M, Fizzman P, Howard A. Mixed connective tissue disease in children. Rheumatol Rehabil $1978 ; 17$ : 245-8.

23 O'Connell D J, Bennett R M. Mixed connective tissue disease-clinical and radiological aspects of 20 cases. Br J Radiol 1977; 50: 620-5.

24 Bennett R M, O'Connell D J. The arthritis of mixed connective tissue disease. Ann Rheum Dis 1978; 37: 397-403.

25 Alarcon-Segovia D, Uribe-Uribe $O$. Mutilans-like arthropathy in mixed connective tissue disease. Arthritis Rheum 1972; 22: 1013-8.

26 Alarcon-Segovia D, Fishbein E, Garcia-Ortigoza E, Estrada-Parra S. Uracil specific anti RNA antibodies in scleroderma. Lancet 1975; i: 363-5. 